\title{
A Rights-Based View of the Idea/Expression Dichotomy in Copyright Law
}

\author{
Abraham Drassinower \\ Version Post-print/accepted manuscript \\ Citation Drassinower, Abraham, A Rights-Based View of the Idea/Expression \\ (published version) Dichotomy in Copyright Law. Canadian Journal of Law and \\ Jurisprudence, Vol. 16, January 2003. \\ Publisher's Statement This article has been published in a revised form in the Canadian \\ Journal of Law and Jurisprudence \\ [https://doi.org/10.1017/s0841820900006603]. This version is free to \\ view and download for private research and study only. Not for re- \\ distribution, re-sale or use in derivative works. (C) Cambridge University \\ Press.
}

How to cite TSpace items

Always cite the published version, so the author(s) will receive recognition through services that track citation counts, e.g. Scopus. If you need to cite the page number of the author manuscript from TSpace because you cannot access the published version, then cite the TSpace version in addition to the published version using the permanent URI (handle) found on the record page.

This article was made openly accessible by $U$ of $T$ Faculty. Please tell us how this access benefits you. Your story matters. 


\title{
A Rights-Based View of the Idea/ Expression Dichotomy in Copyright Law
}

\author{
Abraham Drassinower \\ It would be remarkable if the bipolarity of such litigation did not \\ structure the legal doctrine that it spawned.
}

Ernest J. Weinrib, The Idea of Private Law

\section{Introduction}

The vast landscape of contemporary copyright theory still reveals traces of a once lively and heated struggle between two views of copyright law. On the one hand, there is a view of copyright law as the vindication of the author's natural right to the products of her labour. This rights-based view posits that the inherent dignity of authorial right is the defining axis around which the law of copyright either does or ought to orbit. On the other hand, there is a view of copyright law as a statutory instrument designed to balance incentives necessary for the author's productivity with the public interest in access to and dissemination of her products. This instrumentalist view posits that the author's legal entitlement is but a function of the public interest, a means to an end-albeit a necessary means-not an end in itself. It is fair to say that, at least in North America, the latter of these two orientations is dominant. Prominent among the reasons for that dominance is the widely shared perception that the vindication of the inherent dignity of authorial right is theoretically deficient because it cannot consistently limit the author's entitlementenshrined as a matter of natural right—in light of the public domain. ${ }^{1}$

I would like to thank Peter Benson, Victoria Blond, Richard Bronaugh, Alan Brudner, Bruce Chapman, Andrew Christie, Wendy Gordon, Gillian Hadfield, Michael Meurer, Jim Phillips, Margaret Radin, Sophia Reibetanz, Arthur Ripstein, Catherine Valcke, Arnold Weinrib, and Ernest Weinrib for their comments. I would also like to thank the wonderful students that participated in my "Selected Issues in Copyright Law" Seminar at the University of Toronto Faculty of Law in the Winter of 2001 and in the Fall of 2002. It goes without saying that all errors are mine. Earlier-and longer! — drafts of this paper were presented at the "Intellectual Property Speaker Series," Boston University School of Law, November 2000, and at the "Stanford/Yale Junior Faculty Forum," Stanford Law School, June 2001.

1. For a recent overview of intellectual property theory, see William Fisher, 'Theories of Intellectual Property' in Stephen R. Munzer, ed., New Essays in the Legal and Political Theory of Property (Cambridge: Cambridge University Press, 2001) 168. The dominance of the instrumentalist view is clearer in the United States than in Canada. Nonetheless, the view that the rights-based view is incapable of accounting for the public domain prevails in Canada as well. Consider, for example, the exchange between R.J. Roberts, on the one hand, and A.A. Keyes and C. Brunet, on the other: R.J. Roberts, 'Canadian Copyright: Natural Property or Mere Monopoly' (1979) 40 Can. Patent Reporter (2d) 33; and A.A. Keyes \& C. Brunet, "A Rejoinder to "Canadian Copyright: Natural Property or Mere Monopoly"' (1979) 40 Can. Patent Reporter (2d) 54. See also David Vaver, 'Intellectual Property Today: Of Myths and Paradoxes' (1990) Can. Bar Rev. 98; David Fewer, 'Constitutionalizing Copyright: Freedom of Expression and the Limits of Copyright in Canada' (1997) 55(2) U. T. Fac. L. Rev. 175; John S. McKeown, Fox Canadian Law of Copyright and Industrial Designs 3rd ed. (Scarborough, ON: Carswell, 2000) at 3-4; and Sunny Handa, Copyright Law in Canada (Markham, ON: Butterworths Canada, 2002) at 112-13. 
The central doctrine of copyright law, the idea/expression dichotomy, is a crucial means whereby copyright law limits the scope of the author's entitlement in light of the public domain. The doctrine provides that an author's ideas, no matter how novel, are not subject to copyright protection. Only her expression of those ideas is. Thus the plaintiff in a copyright action must show not that her ideas have been adopted by the defendant, but that the defendant has copied the plaintiff's expression. ${ }^{2}$

One consequence of the dominance of the instrumentalist account of copyright law is the widely shared sense that the rights-based view cannot account for the idea/expression dichotomy. Thus, for example, David Vaver states that " $[t]$ he logic flowing from a concept of natural rights, that ideas should be protected in perpetuity and throughout the world, has never been accepted by even the most ardent promoters of a strict intellectual property regime." ${ }^{\prime 3}$ Along similar lines, David Fewer, to give one more example, states that "[ $\mathrm{t}]$ he natural rights approach fails to account for copyright law's fundamental division between ideas and expression." ${ }^{4}$

This paper formulates a rights-based account of the idea/expression dichotomy. My aim is to unfold and reveal the public dimension that, from the standpoint of a rights-based view, must necessarily inhere in —and therefore limit—-the author's copyright. At stake is the possibility of an account of the public domain from within a rights-based conception of copyright.

Three related points in regard to the scope and aims of this paper are worth stating briefly at the outset. First, I do not claim to offer a rights-based justification of copyright law. My intent is far more modest. I want to undo the widespread assumption that a rights-based justification is inconsistent with an account of the public domain. Thus my intent is less to offer a rights-based justification of copyright law than to question the perceived opposition between author-centred accounts of copyright and the affirmation of the public domain. I am interested in undoing what I take to be a powerful resistance to the rights-based view: the proposition that recognition of the inherent dignity of authorial right cannot help but overlook the claims of the public domain.

Second, my effort to formulate a rights-based defense of the public domain is not intended to reconcile the rights-based view and the dominant instrumentalist view. Rather, it is intended to retrieve the public dimension immanent in the rightsbased view itself. Accordingly, I do not attempt some would-be synthesis of the deontological orientation of the rights-based view and the utilitarian orientation of the instrumentalist view. On the contrary, my claim is that the utilitarianism of the instrumentalist view is not the only basis upon which to produce a theoretical

2. See, for example, Moreau v. St. Vincent [1950] Ex. C.R. 198 at 203 (Can. Ex. Ct.): "It is ... an elementary principle of copyright law that an author has no copyright in ideas but only in his expression of them. The law of copyright does not give him any monopoly in the use of the ideas with which he deals or any property in them, even if they are original. His copyright is confined to the literary work in which he has expressed them. The ideas are public property, the literary work is his own. Every one may freely adopt and use the ideas but no one may copy his literary work without his consent." (Emphasis added).

3. Vaver, supra note 1 at 99-100. See also David Vaver, Copyright Law (Toronto, ON: Irwin Law, 2000) at 8.

4. Fewer, supra note 1 at 188. 
account of the public domain in copyright law. The rights-based view can and does provide its own account. My concern here, then, is with bringing the public dimension of the rights-based view more sharply into relief by way of a rights-based account of the idea/expression dichotomy.

Third, the public domain generated through a rights-based account is admittedly narrower in scope than the public domain that may be derived from an instrumentalist perspective indifferent to the inherent dignity of authorial right. I do not wish to suggest that an insistence to broaden the public domain beyond the requirements of the rights-based account is illegitimate. I do wish to emphasize, however, that such insistence conflates two related yet distinct issues. One is about the extent to which the rights-based view can explain the public domain in copyright law by providing an account of established copyright doctrines that limit the author's entitlement. ${ }^{5}$ This issue — which, by way of the idea/expression dichotomy, is the object of my attention in this paper-is about the extent to which the irreducible principle of authorial dignity that a rights-based account must recognize can generate its own self-limitation.

The other issue involved is about the interaction between the rights-based principle of authorship and other recognized principles to which authorship may be legitimately expected to yield. This is not a question about the limits of the author's right as a copyright matter, but about the relation between copyright law and, for example, the constitutional guarantee of freedom of expression. I will show that the rights-based account of copyright law generates its own internal conception of the limitations to be imposed upon the author's copyright. But this does not mean that the rights-based account precludes the imposition of additional external limits rooted in the operation of other legally recognized interests. It means only that the rights-based account permits and requires a distinction between internal and external modes of limiting the author's right. This is a distinction between the public domain as an aspect internally constitutive of copyright law, and the public interest as representative of a broader set of concerns or principles that may externally impinge on the scope of the author's entitlement. My view is that the rights-based account can and does allow for-though at a different level of analysis - the external concerns that the instrumentalist account conflates with copyright's own internal dynamics. But my aim here is not to analyze the relation between the public domain and the public interest from a rights-based standpoint. My point is prior: namely, that the rights-based account of the idea/expression dichotomy should serve to challenge the dominance of the instrumentalist account of copyright law by establishing that there is no need to conceptualize all limitations of the scope of the author's copyright as an external public interest matter. A rights-based account can generate its own affirmation of the limits of authorial right.

5. Central among these doctrines is, of course, the idea/expression dichotomy. But one may also note, for example, the limited duration of the author's copyright, the doctrine of merger, the requirement of fixation, and the defense of fair dealing. For an effort to account for the American doctrine of "fair use" from a "fairness" standpoint, see Gideon Parchomovsky, 'Fair Use, Efficiency and Corrective Justice' (1997) 3 Legal Theory 347 at 366-67 where Parchomovsky writes: "My point here is not that constraints on rights in works of authorship are never justifiable, but rather that such constraints must be rooted in considerations that respect rights." 


\section{Labour and Intersubjectivity}

Before moving on to the idea/expression dichotomy, I want to make some remarks of a general nature sketching the theoretical context from which this paper arises. Prominent among the handful of North American authors who have recently engaged with the question of a rights-based account of copyright law are Justin Hughes, Alfred Yen and Wendy Gordon. ${ }^{6}$ What their work shares, albeit in different senses and to different extents, is an attempt to find in John Locke's labour theory of property support not only for the author's natural right to her work, but also for the public's countervailing right to limit the author's entitlement. Thus the vindication of the author's natural right on the basis of Locke's labour theory of property appears, from the very outset, as inherently connected to the recognition of the public domain. ${ }^{7}$

My effort to formulate a rights-based approach to copyright challenges the deployment of Locke's labour theory of property in pursuit of that goal. My concern is that, within the purview of Locke's theory, the public domain arises, and must arise, in terms of Locke's famous proviso that the labourer is entitled to the products of her labour, provided that "there is enough, and as good, left in common for others." It may well be true that Locke's proviso operates as a limitation on the right

6. See Justin Hughes, ‘The Philosophy of Intellectual Property' (1988) 77 Georgetown L. J. 287; Alfred C. Yen, 'Restoring the Natural Law: Copyright as Labor and Possession' (1990) 51 Ohio State L.J. 517; Alfred C. Yen, 'The Interdisciplinary Future of Copyright Theory' in Martha Woodmansee \& Peter Jaszi, eds., The Construction of Authorship: Textual Appropriation in Law and Literature (Durham, NC: Duke University Press, 1994)159; and Wendy Gordon, 'A Property Right in Self- Expression: Equality and Individualism in the Natural Law of Intellectual Property' (1993) 102 Yale L.J. 1533.

7. On the public domain, see David Lange, 'Recognizing the Public Domain' (1981) 44 Law \& Contemp. Prob. 147; Jessica Litman, 'The Public Domain' (1990) 39 Emory L.J. 965; and Gordon, 'Equality and Individualism' supra note 6. On Locke's role and influence in the historical emergence of modern copyright law, see Mark Rose, 'The Author as Proprietor: Donaldson v. Becket and the Genealogy of Modern Authorship' in Brad Sherman \& Alain Strowell, eds., Of Authors and Origins: Essays on Copyright Law (Oxford: Clarendon Press, 1994) 23 and Mark Rose, Authors and Owners: The Invention of Copyright (Cambridge, MA: Harvard University Press, 1993). See also Brad Sherman \& Lionel Bentley, The Making of Modern Intellectual Property Law: The British Experience, 1760-1911 (Cambridge: Cambridge University Press, 1999) at 11-42. For comparative discussion of Anglo-American and Continental European copyright doctrine and thought, see Neil Weinstock Netanel, 'Copyright Alienability Restrictions and the Enhancement of Author Autonomy: A Normative Evaluation' (1993) 24 Rutgers L.J. 347. See also Jane C. Ginsburg, 'A Tale of Two Copyrights: Literary Property in Revolutionary France and America' in Brad Sherman \& Alain Strowell, eds., Of Authors and Origins: Essays on Copyright Law (Oxford: Clarendon Press, 1994)131; and Paul Goldstein, 'The Two Cultures of Copyright' Chapter 5 of Paul Goldstein, Copyright's Highway: From Gutenberg to the Celestial Jukebox (New York: Hill and Wang, 1994)165.

8. John Locke, Second Treatise of Government, ed. by C.B. Macpherson (Indianapolis, ID: Hackett Publishing Company, Inc., 1980) at 19. The full text of Locke's famous par. 27 of the Second Treatise reads: "Though the earth, and all inferior creatures, be common to all men, yet every man has a property in his own person: this no body has a right to but himself. The labour of his body, and the work of his hands, we may say, are properly his. Whatsoever then he removes out of the state that nature hath provided, and left it in, he hath mixed his labour with, and joined to it something that is his own, and thereby makes it his property. It being by him removed from the common state nature hath placed it in, it hath by this labour something annexed to it, that excludes the common right of other men: for this labour being the unquestionable property of the labourer, no man but he can have a right to what that is once joined to, at least where there 
to appropriation, and that this limitation, as Wendy Gordon has argued in the context of intellectual property, is perhaps far more powerful than has been generally appreciated. The proviso not only limits the labourer's prima facie claim. In Gordon's account, the proviso in fact enriches and complicates Locke's basic proposition that labour is constitutive of property by casting it in a conceptual context oriented toward not only the author's right in self-expression but also, and simultaneously, toward everyone else's equal and competing right in self-expression. ${ }^{9}$ The limitation enacted through the proviso thus arises either as a 'trump' to a property right that has been previously constituted through labour, or, more precisely, as an obstacle to the maturation into a property right of a prima facie claim to property that, again, has been previously constituted through labour. This means, however, that the deployment of the proviso as a limitation of the labourer's claim leaves unanswered a prior question that is certainly worth posing: namely, the question of whether labour is, to begin with, constitutive of property, whether prima facie or otherwise.

The perennial difficulty with efforts to derive the property right from the category of labour is that whereas labour is a relation between a person and a thing, property is neither a thing nor a relation between a person a thing. It is a relation between persons with respect to things. As Immanuel Kant well knew, this age-old adage already contains the insight that, precisely as a relation between persons, property cannot be derived from a unilateral act—such as labour — of a person on a thing. ${ }^{10}$

Of course, I am by no means suggesting that a thinker of John Locke's stature could have possibly overlooked a proposition as legally and philosophically elementary as the proposition that property is an interpersonal relation. Locke's proviso is after all nothing less than Locke's incorporation of the interpersonal dimension of the property right into his analysis. My concern, rather, is with the way in which the interpersonal or intersubjective dimension of the property right arises in Locke's analysis. As I stated at the outset, I want to formulate the claims of the public domain not in terms of an external limit imposed upon the author but rather in terms

is enough, and as good, left in common for others." (Emphases in original). See also par. 44, at 27: "From all of which it is evident, that though the things of nature are given in common, yet man, by being a master of himself, and proprietor of his own person, and the actions or labour of it, had still in himself the great foundation of property; and that, which made up the great part of what he applied to the support or comfort of his being, when invention and arts had improved the conveniences of life, was perfectly his own, and did not belong in common to others." (Emphasis in original).

9. See Gordon, supra note 6. For a recent interpretation of Locke's theory of property that emphasizes its egalitarian dimension not so much through the related roles of labour and the proviso but rather through the initial common ownership thesis, see Seana Valentine Shiffrin, 'Lockean Arguments for Private Intellectual Property' in Stephen R. Munzer, ed., New Essays in the Legal and Political Theory of Property (Cambridge: Cambridge University Press, 2001)138. For a view of the inegalitarian dimension of Locke's theory, see C.B. Macpherson, The Political Theory of Possessive Individualism: Hobbes to Locke (Oxford: Oxford University Press, 1962).

10. See Immanuel Kant, The Metaphysics of Morals, trans. by Mary Gregor (Cambridge: Cambridge University Press, 1996) at 49-86. For commentary on Kant's theory of property, see Mary Gregor, 'Kant's Theory of Property' (1988) 41 Rev. Metaphysics 757. Kenneth Baynes' 'Kant on Property Rights and the Social Contract' (1989) 72 The Monist 433, includes a section on Kant's critique of Locke. For a critical reading of Kant, see Herbert Marcuse, 'Kant' in Herbert Marcuse, From Luther to Popper, trans. by Joris de Bres (Norfolk, UK: Verso, 1972) at 79-94. On the relation between property and personality, see Margaret Jane Radin, Reinterpreting Property (Chicago: University of Chicago Press, 1993). 
of an unfolding of the very presuppositions of the author's right. My point is that the author's right necessarily offers, as a matter of its own internal logic, its own self-limitation. My hope is to show that the limits of the author's right as a matter of copyright are best grasped by incorporating the interpersonal dimension of the property right more deeply into the analysis of the author's relation to her work. My suspicion is that the dignity of the public domain in the law of copyright can be given its proper due only to the extent that the proposition that the author unilaterally constitutes her copyright through her labour is itself questioned and analyzed.

There can be no doubt that, qua author, an author is indisputably a labourer. She labours in order to give birth to her work. The analysis of authorship is an analysis of the relation between author and work. This analysis can indeed be conducted under the rubric of labour. For it is labour that, as a category denoting a relation between a subject and an object, a person and a thing, mediates the relation between author and work. Thus, for example, the theorist of artistic production may wish to deploy the category of labour in order to denote the creative processes whereby the author's interiority is externalized as oeuvre.

Yet qua proprietor, the author cannot be reduced to her identity as labourer any more than property can be understood as a unilateral relation between a person and a thing. The author is after all a proprietor only in relation to another person. Thus, precisely as a matter of proprietorship rather than authorship, ${ }^{11}$ the analysis of copyright is an analysis not of the relation between author and work but of the relation between author and audience. This analysis must be conducted under the rubric of intersubjectivity. For it is intersubjectivity that, as a category denoting a relation between a subject and a subject, a person and a person, mediates the relation between author and members of the author's audience.

11. On the historical emergence of the author as proprietor, see Mark Rose, 'The Author as Proprietor' supra note 7; Mark Rose, 'The Author in Court: Pope v. Curll (1741)' in The Construction of Authorship, supra note 6 at 211; and Mark Rose, Authors and Owners, supra note 7. See also, Martha Woodmansee, 'On the Author Effect: Recovering Collectivity' in The Construction of Authorship, supra note 6; Martha Woodmansee, 'The Genius and the Copyright: Economic and Legal Conditions of the Emergence of the "Author"' (1984) 17 Eighteenth C. Stud. 425; and Peter Jaszi, 'On the Author Effect: Contemporary Copyright and Collective Creativity' in The Construction of Authorship, supra note 6. Generally speaking, this literature deploys the historicity of authorship in an effort both to unmask the individualized 'modern' author as a 'romantic' fiction and thereby to undermine her claim to proprietorship on the basis of an unveiling of the collective or collaborative nature of intellectual labour and production. My position differs in that it does not share the presupposition that labour-albeit now posited collectively-is constitutive of property. Thus I seek not to question what I regard as the irretrievably individual aspects of the author's labour, but rather to preclude the recalcitrant inference that such labour is constitutive of property. I see no need to give up the concept of individual authorship in order to criticize its exaggerations. I cannot help but suspect that, in seeking to 'deconstruct' authorship in order to criticize proprietorship, post-structuralism seems to fall prey to an unwitting reproduction of the very equation of authorship and proprietorship that is the intended target of critique. Consider in this regard James Boyle, 'Copyright and the Invention of Authorship' in James Boyle, Shamans, Software, and Spleens: Law and the Construction of the Information Society (Cambridge, MA: Harvard University Press, 1996) at 51-60. At page 60, Boyle writes: "The romantic idea of authorship is no more a 'mistake' than classical economics was a mistake. It is both something more and something less than that. If one is critical of a system built on its presuppositions, one must begin by understanding both its authentic appeal and the deep conceptual itches it manages to scratch. Only then can one begin the critique." 
Of course, from the point of view of copyright, this intersubjective nexus between author and members of the author's audience is not at issue as some kind of aesthetic nexus between writer and reader of a work of art. It is at issue, rather, as a specifically legal nexus between holder of right and bearer of duty in respect of an intellectual creation. Thus the theorist of copyright deploys the category of intersubjectivity in order to denote the network of obligation attendant on the relation between the author qua proprietor and members of the author's audience qua unauthorized copyists of the author's oeuvre. The intersubjectivity of copyright is structured as an irreducible correlativity of legal right and duty.

At the same time, however, this insistence upon the intersubjective nature of copyright as a specifically legal phenomenon by no means amounts to a denial of the role of labour in the constitution of copyright. The author's labour is by no means irrelevant to the determination of her legal entitlement to her work. The law of copyright will not protect that which is not a product of the author's labour. The point is, rather, that the law of copyright will not protect every aspect of author's work-i.e., every aspect of the product of the author's labour. On the contrary, the law of copyright protects the author's expression, but not her ideas, even where the latter are assumed to be as much a product of the author's labour as the former. ${ }^{12}$ Hence, the point is not that labour is irrelevant to the constitution of copyright but rather that the legal meaning of the author's labour cannot to be derived from the category of labour itself.

The category "product of the author's labour" is after all wider in scope than the category "author's entitlement to copyright." The latter is a selection drawn from the former. From this point of view, the fundamental question of copyright is a question about the logic, if any, of this selection. It is a question about the logic by which the meaning of the author's labour is legally construed. ${ }^{13}$

This logic is the object of my inquiry. The idea/expression dichotomy amounts to a distinction between authorship and copyright, between the scope of what the author sends into the world (i.e., idea as much as expression) and the narrower scope of what is subject to legal protection (i.e., expression alone). Deploying the concept of copyright as a relation between persons, I want to produce an account of the idea/expression dichotomy that demonstrates that the logic of copyright is, at root, an affirmation of the equality as authors of the parties to a copyright action. To the extent that the defendant has not copied the plaintiff's expression but has instead expressed an idea anew, the defendant has exercised his own authorship. The idea/expression dichotomy permits the defendant to avail himself of ideas in pursuit

12. See Nichols v. Universal Pictures Corporation 45 F.2d 119 (2d Cir. 1930).

13. To raise the problem of copyright as a normative problem is - borrowing Wendy Gordon's formulation - to raise the question of defining the conditions under which beneficial effort (i.e., labour) should generate a noncontractual right to reward. As Gordon has it, the author sends her work into the world in the absence of a promise of return. Hence the question to be raised is that of the conditions under which a lack of payment for the benefits gained by the recipients of this work should be deemed to be "unjust." Gordon aptly suggests that we look to the law of unjust enrichment for guidance in the effort to refine our intuitions about the conceptual coordinates of the normativity of copyright. See Wendy Gordon, 'On Owning Information: Intellectual Property and the Restitutionary Impulse' (1992) 78 Virginia L. Rev. 149. 
of his own original expression - his own authorship. The idea/expression dichotomy thus defines the scope of the plaintiff's copyright from the standpoint of the parties' equality as authors. The plaintiff's assertion of her dignity as an author is legally cognizable only to the extent that such assertion is consistent with the defendant's equal dignity as an author. ${ }^{14}$ Precisely as that of a relation between persons, the logic of copyright is an egalitarian logic. The limits of the plaintiff's right (i.e., the law's refusal to copyright ideas) are the contours of a public domain that, as a matter of equality, the plaintiff herself must be held to recognize. One might say that the public domain is not only a space containing freely available materials. It is also a fundamental condition of free and equal interaction between persons in their capacity as authors. The public's domain is the domain of fair interaction.

Hand J.'s judgement in Nichols remains the locus classicus of the idea/expression dichotomy. In Nichols, the plaintiff was the author of a play entitled "Abie's Irish Rose." The defendant produced a motion picture play entitled "The Cohens and the Kellys," which the plaintiff alleged was taken from her own play. Following a description and comparison of the plays, Hand J. found that "[t]he only matter common to the two is a quarrel between a Jewish and an Irish father, the marriage of their children, the birth of grandchildren and a reconciliation." ${ }^{15}$ On that basis, Hand J. ruled in favour of the defendant: "A comedy based upon conflicts between Irish and Jews, into which the marriage of their children enters, is no more susceptible of copyright than the outline of Romeo and Juliet."16

At no point does Hand J. contest the claim that the defendant "took" from the plaintiff. Hand J.'s point, rather, is that what the defendant took did not belong to the plaintiff, even on the counterfactual assumption that the plaintiff had indeed, as it were, created it ex nihilo:

We assume that the plaintiff's play is altogether original, even to an extent that in fact it is hard to believe. We assume further that, so far as it has been anticipated by earlier plays of which she knew nothing, that fact is immaterial. Still, as we have already said, her copyright did not cover everything that might be drawn from her play; its content went to some extent into the public domain. ${ }^{17}$

What Hand J. had "already said," of course, is that copyright does not protect "ideas":

If the defendant took so much from the plaintiff, it may well have been because her amazing success seemed to prove that this was a subject of enduring popularity. Even so, granting that the plaintiff's play was wholly original, and assuming that novelty is not essential to a copyright, there is no monopoly in such a background. Though the plaintiff discovered the vein, she could not keep it to herself; so defined, the theme

14. My account of the idea/expression dichotomy is indebted to Ernest J. Weinrib's Kantian account of tort law in particular and private law in general in The Idea of Private Law (Cambridge, MA: Harvard University Press, 1995). See also Ernest J. Weinrib, 'Correlativity, Personality, and the Emerging Consensus on Corrective Justice' (2001) 2 Theoretical Inquiries in Law (Online Edition)107. http://www.bepress.com/til/default/vol2/iss1/art4

15. Nichols, supra note 12 at 122.

16. Ibid.

17. Ibid. 
was too generalized an abstraction from what she wrote. It was only a part of her "ideas." 18

The plaintiff's ideas are not copyrightable even though they may be said to have originated in her-and are in that sense "her" ideas-as much as her expression. ${ }^{19}$ Hand J.'s counterfactual assumption makes it abundantly clear that it is pointless to attempt to make the distinction between ideas and expression intelligible in terms of the category of labour. Even assuming the counterfactual that the ideas, like the expression, were a product of the author's labour, Hand J. finds no property right in them. The legal meaning of the author's labour is not in the author's labour.

Yet although the author's copyright is thus limited to her expression, it is not limited "literally to the text." ${ }^{20}$ Otherwise, Hand J. observes, "a plagiarist would escape by immaterial variations." ${ }^{21}$ To limit copyright literally to the text would be as unfair to the plaintiff, it seems, as Hand J. takes it to be unfair to the defendant to grant the plaintiff a monopoly in "stock figures," "prototypes," or in "too generalized an abstraction from what she wrote." The idea/expression dichotomy thus comes to place itself neither on the side of the plaintiff nor in that of the defendant, but rather between plaintiff and defendant, as the guide through which the relation of each and both to the author's oeuvre is given legal meaning.

Famously, Hand J. writes:

Upon any work, and especially upon a play, a great number of patterns of increasing generality will fit equally well, as more and more of the incident is left out. The last may perhaps be no more than the most general statement of what the play is about, and at times might consist only of its title; but there is a point in this series of abstractions where they are no longer protected, since otherwise the playwright could prevent the use of his "ideas," to which, apart from their expression, his property is never extended. ${ }^{22}$

The idea/expression dichotomy, then, raises three distinct yet intimately related questions:

18. Ibid. (Emphasis added.) The distinction Hand J. draws here between "originality" and "novelty" is a distinction between copyright and patent. In patent, novel means new. If I invent something unaware that you have already invented it, my invention is not patentable in that it lacks novelty, and my usage of it, even though it originated in me in the sense that I did not copy it, would amount to an infringement of your patent. But in copyright, original means originating with the author, not copied. Thus, if I rewrite Cervantes' Don Quixote out of myself, so to speak, without copying it, I have not infringed copyright (assuming that the Quixote is under copyright, of course!). For a fictionalized example of such rewriting, see Jorge Luis Borges, "Pierre Menard, Author of the Quixote" in Jorge Luis Borges, Labyrinths: Selected Stories \& Other Writings, trans. by James E. Irby (New York: New Directions, 1964) 36.

19. "Nor does she [the plaintiff] fare better," Hand J. adds, "as to her characters. It is indeed scarcely credible that she should not have been aware of those stock figures, the low comedy Jew and Irishman. The defendant has not taken from her more than their prototypes have contained for many decades. If so, obviously so to generalize her copyright, would allow her to cover what was not original with her. But we need not hold this as a matter of fact, much as we might be justified. Even though we take it that she devised her figures out of her brain de novo, still the defendant was within its rights." See Nichols, supra note 12 at 122. Emphasis added.

20. Ibid. at 121 .

21. Ibid.

22. Ibid. 
(1) Why can the plaintiff not prevent use of her 'own' ideas?

(2) Why can the defendant not use the plaintiff's expression?

(3) How can these two limits respectively imposed upon plaintiff and defendant be grasped not as merely juxtaposed but rather as integrated aspects of a single concept?

\section{Authors and Equality}

The doctrine of originality-i.e., the requirement that she who seeks copyright must be the author of an "original" work-provides a suitable point of access to this threefold constellation. As is well known, "original," in copyright, does not mean novel. Novelty is not a requirement of copyright. An original work is not a novel work but a work that originated with the author, a work that has not been copied. Original means not-copied. ${ }^{23}$

The requirement of originality is therefore inseparable from the defence of "independent creation." The defendant cannot be held liable in copyright where he can show that his work, though identical to or substantially similar to the plaintiff's, was independently created. ${ }^{24}$ For to make out a defence of independent creation is to make out a claim that the defendant's work is not copied.

The defence of independent creation permits the following two observations. The first is that copyright protects the plaintiff's expression-to take the case of

23. "The word 'original' does not in this connection mean that the work must be the expression of original or inventive thought. Copyright Acts are not concerned with the originality of ideas, but with the expression of thought, and, in the case of 'literary work,' with the expression of thought in print or writing. The originality which is required relates to the expression of the thought. But the Act does not require that the expression must be in an original or novel form, but that the work must not be copied from another work-that it should originate from the author." University of London Press Ltd. v. University Tutorial Press Ltd., [1916] 2 Ch. 601 at 608-09. See also CCH Canadian Limited v. The Law Society of Upper Canada, (2002) FCA 187; and Desktop Marketing Systems Pty Ltd. v. Telstra Corporation Limited [2002] FCAFC 112. In the United States, the requirement of originality is a requirement of minimal creativity. In addition to being not-copied, an original work is a minimally creative work. More precisely, the creativity requirement comes to subsume the not-copied requirement. See Feist Publications Inc. v. Rural Telephone Service Co., (1990) 499 U.S. 340. Until recently, such may have been the position in Canada. See Tele-Direct (Publications) Inc. v. American Business Information Inc. (1997), 76 Can. Patent Reporter. (3d) 296 (F.C.A.). The Canadian Federal Court of Appeal has recently, in the Law Society case, either narrowed or reinterpreted the Tele-Direct position so as to render it consistent with the British, rather than the American, position as regards originality. For discussion of the issues involved, see Jessica Litman, 'After Feist' (1992) 17 U. Dayton L. Rev. 607; Norman Siebrasse, 'Copyright in Facts and Information: Feist Publications Is Not, and Should Not Be, the Law in Canada' (1994) 11 Canadian Intellectual Property Review 191; David Fewer, ‘A Sui Generis Right to Data? A Canadian Position' (1998) 30 Canadian Business L.J. 165; Robert G. Howell, 'Database Protection and Canadian Laws: State of Law as of June 15, 1998' available at http://strategis.ic.gc.ca/SSG/ip01044e.html; Graham A. Knight, 'The Fall and Rise of Sweat of the Brow' (1999) 13 Intellectual Property Journal 337; Howard P. Knopf, 'The Database Dilemma in Canada: Is “Ultra” Copyright Required?' (1999) 48 University of New Brunswick L.J. 163; Howard P. Knopf, 'A Tale of Two Columns: Confusion Concerning Compilation Copyright in Canada' (2001) 23(8) Euro. Intell. Prop. Rev.388; Barry Sookman, Computer, Internet and Electronic Commerce Law, looseleaf (Toronto, ON: Carswell, 2001) at 3-111-3-132.3; and Myra Tawfik, 'Decompiling the Federal Court of Appeal's "NAFTA Argument" in Tele-Direct (Publications) Inc. v. American Business Information Inc.- - From Facts to Fiction' (2001-2002) 33 Ottawa L. Rev. 147.

24. See, for example, Kilvington Brothers Ltd. v. Goldberg (1957), 8 D.L.R. (2d) 768 (Ont. H.C.). 
literary works - not as a particular sequence of words belonging exclusively to the plaintiff, but rather as a particular sequence of words originating in the plaintiff. For if the sequence of words were protected as a sequence of words belonging to the plaintiff, then an identity between the defendant's work and the plaintiff's work would amount to an infringement of the plaintiff's copyright, regardless of independent creation by the defendant. Thus the defence of independent creation means that it is not the sequence of words as such but rather the sequence of words as exteriorized or expressed that is subject to copyright protection. The law of copyright conceptualizes the author's work not as an external object in and of itself but as the embodiment of the author's interiority or personality. Copyright protects the work not as object but as expression. It protects not the work but the link between author and work. ${ }^{25}$ The substance of this link is the author's right to her expression.

The second observation made possible by the defence of independent creation is that the plaintiff's right to her expression is limited by the requirement that it be consistent with the defendant's equal right to the defendant's own original expression. The plaintiff has a right to her expression only to the extent that her right does not violate the defendant's parallel right to his expression. The defence of independent creation is but an insistence on this limit. If the plaintiff has a right to her original expression, then so must the defendant. Precisely because she claims her work as that which originates in her, the plaintiff cannot, in a world premised on equality, consistently deny the defendant's entitlement to what originates in the defendant, even if what originates in the defendant happens to be identical to or substantially similar to the plaintiff's. The defence of independent creation thus emblematizes the equality of the parties. It teaches us that as soon as the law of copyright grants an author rights in her expression, the law of copyright demands that the author submit to every other person's right in his original expression. The defence of independent creation is but a way to affirm the parties' equal entitlement to original expression.

The point is that the plaintiff cannot claim an interest whose assertion amounts to a denial of the very possibility of the defendant's assertion of that same interest. My claim that another person respect what originates in me as mine binds me to accept that person's reciprocal claim that I respect what originates in him as his. As the defence of independent creation reveals, the category of originality is through and through a bilateral category. It formulates copyright not as a unilateral relation between author and work but rather as a bilateral relation between persons through the work. As that which gives rise to copyright, originality is not merely about the legal link between author and work. It is also, and necessarily, about the author's relation to other persons. From the very outset, the law of copyright interprets the author's labour intersubjectively.

Nothing in the defence of independent creation suggests that, for the defence to operate, the defendant must show that he had no alternative but to create a work that happened to be substantially similar to the plaintiff's. The defence of independent creation is indifferent to the question of whether the defendant could have

25. See Immanuel Kant, 'On the Wrongfulness of Unauthorized Publication of Books' in Practical Philosophy, trans. and ed. by Mary J. Gregor (Cambridge: Cambridge University Press, 1996). 
created something other than what the plaintiff happened to have created. That is, the defence of independent creation operates even if the plaintiff's creation leaves enough and as good alternative possibilities of creative expression for the defendant to follow. The point, then, is not that the author must leave "enough, and as good," for others. The point, rather, is that the author's right must stop short of amounting to a denial of the defendant's equal right to authorship.

The parties' status as equally entitled to their own expression-i.e., their equality as authors-already contains an understanding of the idea/expression dichotomy. Assume for a moment that you use or adopt in your own work an idea drawn from another person's work, yet without copying that other person's expression of the idea. Say, for example, that you write an original play developing the idea of "starcrossed lovers." This means not that you have reproduced the text of Romeo and Juliet (i.e., William Shakespeare's expression of that idea), but that you have expressed the idea anew. To use in one's own work ideas drawn from another's is necessarily to exercise one's own expressive capacities. Strictly speaking, we might say that ideas per se cannot be copied; they can only be (re-) expressed anew. This is why the copyright case law speaks not of copying ideas but of "adopting" or "using" them. ${ }^{26}$ The lesson to be drawn from such formulations is that a plaintiff seeking to enjoin a defendant from using or adopting in the defendant's own work ideas expressed in the plaintiff's work is a plaintiff seeking to interfere with the defendant's own original expression.

Where the defendant expresses an idea in his own words, the plaintiff cannot complain of a violation of her copyright because her own claim to copyright is but an affirmation that persons have a right to their expression. What the plaintiff would have to assert in order to claim copyright in an idea is that she, but not the defendant, has rights in her expression. Yet that assertion would, of course, be inconsistent with the equality of the parties considered in their capacity as authors, as originators of copyrightable expression. The proposition that only expression is copyrightable, and not ideas, is thus necessarily rooted in the equality of the parties as authors. Just as the defence of independent creation precludes the defendant's liability even where the defendant's work is identical to the plaintiff's, so does the idea/expression dichotomy preclude the defendant's liability even where the defendant's work draws ideas from the plaintiff's. In neither case does the law of copyright permit the plaintiff to interfere with the defendant's entitlement to his own expression. In both cases, respect of the defendant's expression is the condition sine qua non of the plaintiff's own copyright. In short, copyrighting ideas is inconsistent with the doctrine of originality and its normatively necessary corollary, the defence of independent creation.

It is true, of course, that to suggest that this inconsistency between the doctrine of originality and the copyrighting of ideas amounts to an account of the idea/expression dichotomy is to presuppose that the definition of originality exclusively as expression originating in the author is itself justified. That is, while it may well be true that copyrighting ideas is incompatible with the way in which the law

26. See, for example, Moreau v. St. Vincent, supra note 2 at 203: "Every one may freely adopt and use the ideas but no one may copy his literary work without his consent." (Emphasis added) 
of copyright defines originality, this does not yet explain why the law of copyright defines originality as pertinent only to expression, and not to idea. What, then, is it that informs the necessity to define authorship exclusively as a matter of expression rather than ideation? Why is it that copyright protects only expression?

Imagine a plaintiff that, having come up with an indisputably novel idea, complained that, even if copyrighting ideas is inconsistent with the definition of originality, there is nonetheless nothing in the concept of the parties' equality as authors that necessitates such a definition. Such a plaintiff may argue as follows: "I want to claim not that I have a right to my own expression but that I have a right to what originates in me, regardless of whether it is expression or idea. This novel idea here, and not only its expression, originated in me. I have no problem in acknowledging that others, too, have a right to the exclusive use of the ideas that they themselves originate. Nor do I have any difficulty in acknowledging a defence of independent ideation. Thus nothing in my claim to copyright my novel idea contradicts everyone else's status as originators of ideas, if and when they in fact come up, as I have, with a novel idea of their own. The law of copyright ought to affirm our equality not only as expressive beings but also as thinking beings, not only as beings who originate expression but also as beings who originate ideas."

It goes without saying, of course, that this plaintiff's position has no legal weight. Even if we were to assume, as does Hand J. in Nichols, that the plaintiff truly originated an idea de novo, it is abundantly clear that the law of copyright would not grant her protection of that idea. But the question here is not whether the plaintiff would succeed in court. Rather, the plaintiff's objection demands that we understand why the law of copyright finds authorship in expression but not equally in idea.

The beginning of the answer lies in the observation that, considered as bare ideation, the plaintiff's thought cannot help but be legally irrelevant. This is because, as distinct from her identity as an expressive being, the plaintiff's identity as a thinking being is a matter thoroughly internal to the plaintiff, outside the purview of the plaintiff's relation to others. It is expression, not ideation, that renders thought a matter of right, that plunges thought into the field of intersubjectivity. On this view, the reason that copyright law refuses to protect ideas is that ideas can be said to enter the sphere of right, of relations between persons, only as expressed. Thus, for example, the plaintiff cannot claim an entitlement to her thoughts, or as arising exclusively from her thoughts, any more than, in the context of first possession in the world of real property, a plaintiff can claim that her bare intention to possess an object, in the absence of an unequivocal and publicly recognizable manifestation of that intention, is sufficient to constitute another person's obligation to refrain from using the allegedly possessed object. ${ }^{27}$ Ideas are no more relevant in copyright than mere intentions are in the context of first possession. So serious is the law

27. See Pierson v. Post 3 Cai, R. 175 (N.Y. Sup. Ct. 1805). For commentary, see Carol M. Rose, 'Possession as the Origin of Property' in Carol M. Rose, Property and Persuasion: Essays on the History, Theory, and Rhetoric of Ownership (Boulder, CO: Westview Press, 1994); and Peter Benson, 'The Idea of Property in Private Law' in The Oxford Handbook of Jurisprudence and Philosophy of Law, ed. by Jules Coleman \& Scott Shapiro (Oxford: Oxford University Press, 2002) at 752. 
of copyright about the necessity for an author's externally recognizable manifestation of her thought that it in fact refuses to copyright expression itself where such expression is not "fixed" in tangible form..$^{28}$

As distinct from what we may call the merely subjective emptiness of bare ideation, expression is always expression toward another. An author is not someone who just thinks; she is also someone who expresses her thoughts. Not the subjectivity of thought but the intersubjectivity of communication is at the heart of the legal concept of authorship. One might even say that it is precisely the transition from thought to communication, inchoate intention to manifested word, that the law of copyright calls authorship. Copyright, then, is necessarily copyright in expression because only expression, not ideation, can have legal import.

While correct as far as it goes, the proposition that the interiority of ideas excludes them from copyright protection is nonetheless insufficient as an account of the idea/expression dichotomy. The difficulty is that the distinction between 'idea' and 'expression' in copyright law is not simply a distinction between 'internal' and 'external.' Thus in Nichols the defendant is said to be within her rights in adopting the plaintiff's ideas, but, of course, she could have hardly adopted them had they remained merely internal to the plaintiff. On the contrary, the ideas had indeed been communicated to the defendant. This means that, while it is undeniably true that ideas can enter the world of legality only as communicated, it is equally true that not every instance of communication is, by that token alone, an instance of copyrightable expression. The idea/expression dichotomy bifurcates the external field of communication between people into aspects that are not subject to legal protection-i.e., idea — and aspects that are-i.e., expression. Our question is how this bifurcation is to be understood from the standpoint of the equality of the parties as authors.

What Hand J. tells us in Nichols is that the plaintiff's ideas are "too generalized an abstraction from what she wrote" 29 to be worthy of copyright protection. The "less developed the characters," he writes elsewhere in the judgment, "the less they can be copyrighted; that is the penalty an author must bear for marking them too indistinctly." ${ }^{30}$ The contrast between ideas and expression is a contrast between the generality of ideas and the specificity of expression. By the same token, the work of authorship is the translation or development of general into specific, abstract into concrete, idea into expression. What matters is not the source of the idea - whether 'internal' or 'external.' What matters is its particularization.

28. See Canadian Admiral Corporation ltd. v. Rediffusion Inc., [1954] Ex. C.R. 382; Gould Estate v. Stoddart Publishing Co. (1996), 30 O.R. (3d) 520 (Gen.Div.). I do not intend to enter here into the question whether, normatively speaking, fixation ought to be a necessary dimension of copyrightability. That may or may not be the case. For an objection to the fixation requirement, see David J. Brennan \& Andrew Christie, 'Spoken Words and Copyright Subsistence in AngloAmerican Law' (2000) 4 I.P.Q. 309. My point is that copyright can protect only what is externally recognizable. If the requirement of external recognizability can be met otherwise than through fixation, then at least that function of the fixation requirement would have already been fulfilled. In fact, even in the context of first possession in the world of real property, the acts required to make out 'possession' vary according to the nature of the object in question. See, for example, The "Tubantia” [1924] All ER 615 (Pr. \& Ad. Div).

29. Nichols, supra note 12 at 122 .

30. Nichols, supra note 12 at 121. 
From this point of view, the idea/expression dichotomy is less about the interiority of ideas than about their generality. Even if communicated, ideas are not per se subject to copyright protection due to their inherent generality. Considered in their bare generality, ideas are the material but not the product of the work of authorship. This is true of ideas communicated at too high a level of generality (such as "stock figures" or "prototypes"), as well as of ideas underlying thoroughly concretized expression (such as "too generalized an abstraction" from an author's work). Authors do not author ideas; they author expressions. An author's work is the expression of an idea, and it is only as expressed, as particularized, that he can lay claim to it. Thus Shakespeare is the author of Romeo and Juliet, not of the idea of "star-crossed lovers," and this would remain true regardless of the source of the idea; that is, regardless of whether anyone before Shakespeare had either thought of or communicated the idea.

The fact that Shakespeare wrote $a$ story about "star-crossed lovers" cannot mean that he has a proprietary claim on all stories about "star-crossed lovers." It is the claim to exclusive use at the level of bare generality that would render the copyright of ideas inconsistent with another's equal dignity as an author. This is why copyright can arise only at the point where the plaintiff's claim to the specificity of her expression is no longer inconsistent with the defendant's claim to his original expression, to his own translation of general into particular. For it is only at that point that, having marked its subject matter with sufficient distinctiveness, the plaintiff's claim is no longer, by virtue of its inchoate generality, inconsistent with the defendant's equal claim to authorship. As a matter of copyright, authorship has nothing to do with bare ideas, whether novel or otherwise.

It is tempting to infer that the law of copyright refuses to protect ideas because ideas are not the kind of thing that can be marked with sufficient distinctiveness. Ideas, one might say, cannot be possessed or occupied. That much seems clear. ${ }^{31}$ I do not need to rehearse here either the extraordinary difficulties attendant on demarcating a mere idea as subject to a proprietary entitlement, or the equally insurmountable obstacles that would accompany any serious inquiry into the origin of something as elusive as an idea. ${ }^{32}$ The point here, however, is not so much that ideas cannot be occupied or possessed, but rather that they cannot be occupied or possessed in their bare generality in a manner consistent with another's equal dignity

31. I hesitate because the doctrine of merger seems to contemplate the possibility that ideas may be 'possessed' or 'occupied.' The doctrine provides that "[i]f an idea can be expressed in only one or in a very limited number of ways, then copyright of that expression will be refused for it would give the originator of the idea a virtual monopoly on the idea. In such a case it is said that the expression merges with the idea and thus is not copyrightable." See Delrina Corporation v. Triolet Systems Inc. (1993), 47 C.P.R. (3d) 1 (Ont. Gen. Div.) at 41. See also Morrissey v. Procter \& Gamble Company, 379 F.2d 675 (1st Cir. 1967); and Herbert Rosenthal Jewelry Corporation v. Kalpakian, 446 F.2d 738 (9th Cir. 1971). Thus it is as if the law of copyright refuses protection precisely at the point where expression most closely resembles exclusive "possession' or 'occupation' of an idea. To be sure, the problem of occupation may be a reason why the law refuses to copyright ideas. Nonetheless, the doctrine of merger suggests that the problem of occupation, considered as an evidentiary problem, cannot be the whole of the story.

32. See, for example, Litman, supra note 7; and Yen, 'Restoring the Natural Law' supra note 6. See also Norman Siebrasse, 'A Property Rights Theory of the Limits of Copyright' (2001) 51 U.T.L.J. 1. 
as an author; that is, in a manner consistent with another's claim to his original expression. The exclusion of ideas from the purview of copyright is thus an instance of the normativity of copyright as a bilateral relation between persons. The legal definition of the plaintiff's copyrightable work is therefore not so much-or not only—an evidentiary matter, as much as a normative exercise conducted under the rubric of interpersonal bilaterality.

\section{An Author among Authors}

The law of copyright, then, formulates the acquisition of the author's right in terms of the author's labour. The doctrine of originality provides that the author's labour of origination is a prerequisite of copyright protection. The author acquires his copyright in and through her labour. Nonetheless, the law of copyright does not formulate either the subject matter or the scope of the author's right in terms of the category of labour. The idea/expression dichotomy is the paradigmatic example of the basic and fundamental proposition that the law of copyright does not protect the author's labour per se. All that is copyrightable originates in the author's labour, but not everything originating in the author's labour is subject to copyright protection. The idea/expression dichotomy differentiates the domain of the author's copyright (i.e., expression) out of the larger expanse of the author's labour (i.e., idea and expression). It can do this only by way of a deployment of a category other than labour itself. This other category is that of the equality of the parties to a copyright action as authors. Thus, while the plaintiff's authorship is recognized in the requirement that the defendant not copy her expression, the possibility of the defendant's authorship is preserved and recognized in the free availability of the ideas expressed. In short, the equality of the parties is affirmed in the simple proposition that the defendant may draw from but not copy the plaintiff's work.

I can now offer the following answers to the three questions that I raised earlier. First, the plaintiff cannot prevent use of her 'own' ideas because to copyright an idea is to find infringement even where the idea has been originally expressed anew by another. The inadequacy of any effort to copyright ideas thus manifests itself in the denial of another's entitlement to her original expression that such copyright would entail. The plaintiff's ideas cannot be copyrighted in the name of the protection of the plaintiff's authorship because the copyright of ideas in fact denies the possibility of the defendant's authorship. The plaintiff can claim authorship only as an author among authors. The defendant cannot be held to have a duty to respect in the plaintiff what the plaintiff_-by way of an effort to copyright 'her' ideas-refuses to respect in the defendant. Second, the defendant cannot use the plaintiff's expression because, just as the copyright of ideas amounts to a denial of the defendant's authorship, so does the defendant's unauthorized copying of the plaintiff's expression amount to a denial of the plaintiff's. The defendant cannot claim the plaintiff's expression as a matter of right because the defendant's unauthorized copying of the plaintiff's expression is a denial of the possibility of entitlement in expression. It follows that what precludes the plaintiff from copyrighting ideas-i.e., the equality of the parties as entitled to their original expression-is 
precisely what precludes the defendant from unauthorized use of the plaintiff's expression. Thus the two limits respectively imposed upon plaintiff and defendant reveal themselves not as merely juxtaposed but rather as integrated aspects of a single concept — that of the correlativity of legal right and duty.

This differentiated unity is the unity of copyright as a relation between persons considered in their equality as authors: it is the intersubjective relation between plaintiff and defendant with respect to the plaintiff's copyrightable work. The idea/expression dichotomy is neither on the side of the plaintiff nor on that of the defendant because it is rather the instantiation of their equality. From this point of view, the public domain is the domain of the defendant's authorship. To recognize the public domain is to recognize the defendant's dignity as an author. The limits of the plaintiff's right are the contours of a public domain that, as a matter of equality, the plaintiff herself must be held to both posit and recognize.

The public dimension inherent in authorial right emerges clearly once copyright is grasped not as a relation between author and work but as a relation between persons with respect to the work. From this perspective, the public domain is not externally imposed upon but internally constitutive of authorial right. This is because the author's copyright necessarily entails an affirmation of the equal authorship of those it seeks to obligate. The defendant's equal dignity as an author is the concept by way of which a rights-based approach to copyright law insists upon the preservation of and cultivation of the public domain.

\section{Concluding Remarks}

The struggle between the rights-based view and the instrumentalist view is not by any means new. Its basic structure already permeated the great 'literary property' debate that surrounded the interpretation of the world's first copyright statute, the Statute of Anne, in 18th century England. ${ }^{33}$ Argued under the aegis of that statute, the landmark case of Donaldson v. Beckett ${ }^{34}$ dramatized the paradigmatic opposition between those who, on the plaintiff's side, insisted upon the author's copyright as a perpetual common law right, and those who, on the defendant's side, asserted the author's copyright as a strictly limited statutory right lasting no longer than the statutorily specified term. ${ }^{35}$ The House of Lords held in favour of the defendant, and the subsequent evolution of copyright law, especially in the North American context, has been taken by many to leave little reason to doubt the proposition that, as a statutory creation, copyright is not a vindication of authorial right but a policy instrument designed in the name of the public interest. ${ }^{36}$

33. 8 Anne, c. 19 (1710). On the 'literary property' debate, see Rose, 'The Author as Proprietor' supra note 7; and Sherman \& Bentley, supra note 7.

34. 98 Eng. Rep. 257 (1774).

35. See Rose, "The Author as Proprietor," supra note 7; and Sherman \& Bentley, supra note 7.

36. Thus, in Canada, the Supreme Court has stated, in Compo Co. Ltd. v. Blue Crest Music Inc. (1979), 105 D.L.R. (3d) 249 at 261 (S.C.C.), that “... copyright law is neither tort law nor property law in classification, but is statutory law. It neither cuts across existing rights in property or contract nor falls in between rights and obligations heretofore existing in the common law. Copyright legislation simply creates rights and obligations upon the terms and in the circumstances set out 
Yet in spite of the apparent affinity between the instrumentalist view and public interest concerns, the scope of the author's legal entitlement has undergone-and continues to undergo - significant expansion since the days of Donaldson v. Beckett. In fact, concern with the dizzying growth of the author's entitlement has, particularly in the latter half of the 20th century, generated a venerable tradition of copyright criticism that, beginning with Benjamin Kaplan's classic, An Unhurried View of Copyright ${ }^{37}$ insists upon the pressing need to reevaluate the current state of the law of copyright so as to save it from its own expansive exaggerations. ${ }^{38}$

There is nothing inherently surprising about that expansion. The fact that it has taken place under the dominance of the instrumentalist account reveals only that a theoretical position premised upon and committed to the public interest is not thereby either premised upon or committed to the public domain. The instrumentalist view regards both the author's right and the public domain as means to the maximization of the public interest in the production and dissemination of intellectual works. Thus, though there may be an intuitive affinity between the public interest and the public domain, nothing in the instrumentalist account of copyright law is in principle opposed to a minimalist conception of the public domain. Within the instrumentalist discourse, the question of the public domain, like that of the author's right, is a question about the requirements of the public interest, and the public interest may well require a severely constricted public domain. One might say that whereas the public domain is an aspect of copyright law, the public interest is the goal that, in the instrumentalist view, copyright law, including the public domain, serves.

in the statute. This creature of statute has been known to the law of England at least since the days of Queen Anne when the first copyright statute was passed. It does not assist the interpretative analysis to import tort concepts. The legislation speaks for itself and the actions of the appellant must be measured according to the terms of the statute." In the U.S., the instrumentalist view has nothing less than constitutional lineage. U.S. Const. art I, $\S 8$, cl. 8 states that "Congress shall be empowered ... To promote the Progress of Science and the useful Arts, by securing for limited Times to Authors and Inventors the exclusive Rights to their respective Writings and Discoveries ...." But see Yen's suggestive discussion of the clause in "Restoring the Natural Law," supra note 6 . The received wisdom is that, historically speaking, the basic structure of the "literary property' debate opposed those who asserted the common law origins of copyright as a matter of natural right to those who insisted upon its exclusively statutory source as a state-granted monopoly. Thus the contrast between common law copyright and statutory copyright is often seen as a distinction between rights-based and utilitarian accounts of copyright. Conceptually speaking, however, nothing precludes the view that a copyright statute is but a recognition and affirmation of authorial dignity. Nor is there anything conceptual precluding the view that common law copyright was itself nothing more than the result of utilitarian reasoning.

37. Benjamin Kaplan, An Unhurried View of Copyright (New York: Columbia University Press, 1967).

38. See, for example, Lange, supra note 7; Litman, supra note 7; Gordon, supra note 6; Gordon, supra note 13; Jeremy Waldron, 'From Authors to Copiers: Individual Rights and Social Values in Intellectual Property' (1993) 68 Chi.-Kent L. Rev. 841; Barbara Friedman, 'From Deontology to Dialogue: The Cultural Consequences of Copyright' (1994) Cardozo Arts \& Entertainment L.J. 157; Neil Weinstock Netanel, 'Copyright and a Democratic Civil Society' (1996) 106 Yale L.J. 283; Fewer, supra note 1; Jessica Litman, Digital Copyright (Amherst, NY: Prometheus Books, 2001). See also Margaret Jane Radin \& R. Polk Wagner, 'The Myth of Private Ordering: Rediscovering Legal Realism in Cyberspace' (1998) 73 Chi.-Kent L. Rev. 1295. For criticism of what he calls "the public domain club," see Edward Samuels, "The Public Domain in Copyright Law’ (1993) 41 J. Copyright Society 137. 
There can be no doubt that, faced with a history that increasingly constricts the public domain in the name of the public interest, the recurrent effort to cure the law of copyright from its expansive exaggerations can perhaps invoke not the public interest as such but rather a particularized conception of the public interest for which a vibrant—or at least a more than minimal—public domain is non-negotiable. ${ }^{39}$ But nor can there be any doubt that, though no longer within the parameters of instrumentalist discourse, the critique of the exaggerated expansions of authorial right can also affirm the inherent worth of the public domain from a rights-based perspective. The foregoing reflection is an attempt to evoke the latter possibility. Its basic point is that, contrary to still widespread impressions, the rights-based account regards both the author's right and the public domain as a matter of inherent dignity. Given that, historically speaking, the exaggerated expansions of authorial interest have in large part taken place under the official rubric of instrumentalism, one cannot help but wonder whether the dignity of the public domain is best grasped, preserved, and cultivated from a rights-based standpoint — the standpoint of authorship itself.

To be sure, as I noted at the outset, the rights-based account raises difficult questions about the interaction between the principle of authorship and other recognized principles to which authorship may be legitimately expected to yield. This means that the rights-based account distinguishes between the kinds of limits that may be imposed upon authorial right. Thus, for example, the rights-based account distinguishes between the law of copyright's refusal to protect ideas, on the one hand, and, on the other, the possible determination that the constitutional guarantee of freedom of expression should under certain circumstances permit use of an author's otherwise copyrightable expression. Both situations suggest limits imposed on the author's entitlement. But the source of each of these limits is not the same. The law of copyright refuses to protect ideas in the name of authorship. The constitutional guarantee of freedom of expression would suspend an author's copyright in the name of a particular vision of democratic life and culture. Prima facie, the concept and language of right permeate each of these limits. And yet, the potential of a rights-based account of copyright law for an investigation of the interaction between authorial right and democratic culture, between authors and citizens, remains largely untapped. Depriving ourselves of that potential on the grounds that the rights-based account cannot generate an affirmation of the public domain would be a regrettable error.

39. See, for example, Netanel, ibid. William Fisher describes this approach as "similar to utilitarianism in its teleological orientation, but dissimilar in its willingness to deploy visions of a desirable society richer than the conceptions of 'social welfare' deployed by utilitarians." See Fisher, supra note 1 at 172 . 
01 Drassinower 19 1/27/08 4:32 PM Page 22 